[Vicino Oriente XVI (2012), pp. 41-53]

\title{
A NEW RECONSTRUCTION OF THE ANKLETS OF PRINCESS KHNUMIT
}

\author{
Ingrid Melandri - Sapienza University of Rome
}

\begin{abstract}
Oltre un secolo fa, nel corso degli scavi di De Morgan presso il complesso funerario di Amenemhat II a Dahshur furono rinvenuti, nella tomba della principessa Khnumit, due pendenti a forma di artiglio pertinenti a una coppia di cavigliere. Il confronto con i più recenti rinvenimenti, effettuati da D. Arnold presso il complesso funerario di Amenemhat III nel medesimo sito, ha consentito di avanzare una nuova proposta di ricostruzione e un'attribuzione dei reperti a una specifica tipologia di ornamenti caratteristica del Medio Regno egiziano.
\end{abstract}

Keywords: jewellery; Dahshur; anklets; Khnumit; Egyptian Museum-Cairo

\section{PREMISE}

Between the end of the nineteenth and the beginning of the twentieth century some exceptional discoveries of precious ornaments related to sisters, wives and daughters of the pharaohs of the XII dynasty occurred, which contributed to an increased knowledge of the artistic production and the symbolic-religious universe of the Egyptian Middle Kingdom.

The aim of this paper is a proposal to reconstruct some elements belonging to a pair of anklets discovered among the personal ornaments of princess Khnumit ${ }^{1}$ in her tomb inside the funerary complex of Amenemhat II at Dahshur. ${ }^{2}$

These artifacts today kept in Cairo Egyptian Museum, ${ }^{3}$ were studied by C. Aldred in his volume on Egyptian jewellery of $1971 .{ }^{4}$ The present reevaluation starts from the most recent discovery by the Metropolitan Museum mission directed by D. Arnold, of another small group of jewels ${ }^{5}$ overlooked by plundering, in the tomb of queen Weret II, inside the funerary complex of Amenemhat III at Dahshur. ${ }^{6}$

\section{The excavations of De Morgan (1894) And ARnold (1994) in the Royal} NECROPOLIS AT DAHSHUR

Jacques Jean-Marie De Morgan, during the second season of excavations at Dahshur (winter 1894-1895), focused his research on the funerary monument of the pharaoh Amenemhat II.

On the western side of the pyramid, the space between this and the enclosure wall is larger than on the northern and southern sides because the tombs of the princesses Ita, Khnumit and Itaweret, all daughters of the sovereign, were located in this area.

On February 12, 1895 one of the trenches in the northwest side of the area revealed a

1 Daughter of Amenemhat II, sister of Ita, Itaweret and Sithathormerit (buried with her in the same funerary complex as her father) and of Sesostris II.

2 De Morgan 1903, 59, n. 11, pl. V.

3 Vernier 1925, 303, pl. LXXI:52.911-52.912.

$4 \quad$ Aldred 1971, 28, fig. 12.

5 Oppenheim 1996, 26; Oppenheim 1999, 146-147; Oppenheim 2002, 128.

6 Arnold 2002, 81-82, fig. 26, pl. 64d. 
large rectangular pit, still with its original filling.

Six metres below De Morgan discovered some limestone blocks that were the covering of a hypogeal monument and he found that the tunnel excavated by the thieves that, fortunately, missed the entrance of the tombs: the two burials inside the massive structure remained untouched.

Each burial chamber had the exact dimensions needed to contain the big sandstone sarcophagus placed there during the construction; at the moment of the burial the lid was set in position and the limestone blocks were placed on it. ${ }^{7}$

First was open the tomb of princess Ita, then that of Khnumit (fig. 1) in which there were some ornaments placed on the body of the deceased and a deposit with other jewels hidden below the pavement of the offering chamber ${ }^{8}$ (tab. 1).

\begin{tabular}{|c|c|}
\hline \multicolumn{2}{|c|}{ JEWELLERY FROM THE TOMB OF PRINCESS KHNUMIT } \\
\hline JEWELS ON THE MUMMY ${ }^{9}$ & JEWELS INSIDE THE CASKET ${ }^{10}$ \\
\hline $\begin{array}{l}\text { Usekh necklace with inlaid hieroglyphs and two } \\
\text { falcon's heads adorning the ends of the collar }\end{array}$ & $\begin{array}{l}\text { Two diadems: one resembles a bush consisting of gold } \\
\text { wires with flowers and six inlaid quatrefoils of papyrus- } \\
\text { heads; one composed of stylized, inlaid vegetal elements, } \\
\text { with a vulture on the front and a tree branch on the rear }\end{array}$ \\
\hline $\begin{array}{l}\text { Multicolored ankh (originally belonged to a } \\
\text { necklace?) }\end{array}$ & Eight motto-clasps (originally belonged to armlets?) \\
\hline Two sa bracelets & $\begin{array}{l}\text { Necklace with ten pairs of hieroglyphs, multicolored drop } \\
\text { pendants and terminated by two inlaid falcon's heads }\end{array}$ \\
\hline Two claw-pendant anklets ${ }^{11}$ & $\begin{array}{l}\text { Group of jewels characterised by the techniques of } \\
\text { granulation and filigree }\end{array}$ \\
\hline
\end{tabular}

Tab. 1: Schematic summary of the jewels discovered in the tomb of princess Khnumit.

In 1990 the "Egyptian Expedition" of the Metropolitan Museum of Art (MMA), directed by Dieter Arnold, reactivated fieldwork, one century after De Morgan's research at the site of Dahshur; in particular, on the pyramid complex of the pharaoh Sesostris III.

The investigations were focused on the study of the general architectural features and constructive techniques as well as on the three southern pyramids.

Pyramids 7, 8 and 9 lie to the south of the king's pyramid, ${ }^{12}$ forming a separate group. They seem to belong to the original plan of the complex, as was confirmed by the discovery of the burial chamber of pyramid 9, which must have been constructed before the king's pyramid was built since its construction shaft is covered by his pyramid.

Pyramids 7 and 8 do not seem to have actual burial chambers, only small underground facilities for the burial of statues, canopic outfits, or other ritual equipment, so it is not sure

\footnotetext{
De Morgan 1903, 42, figs. 97-98.

De Morgan 1903, 56

De Morgan 1903, 58-60.

De Morgan 1903, 61-68.

De Morgan 1903, 59, pl. V:11.

Arnold 2002, plan I.
} 
whether they were meant to be traditional pyramid tombs or cenotaphs. ${ }^{13}$

Pyramid 8 was identified as the funerary monument of Weret I, mother of Sesostris III, while pyramid 9 (fig. 2) was revealed to be that of queen Weret II, wife of the same sovereign.

This structure is set on one level and, like a royal tomb, contains a true antechamber and a vaulted crypt containing a granite sarcophagus; another element common to royal tombs is a separate chamber that houses the canopic niche.

The three rooms are not aligned along a central axis but instead are skillfully placed at right angles to each other, creating a square ground plan.

When the mission of MMA entered the tomb there were the traces of old plundering everywhere: broken vases, fragments of the wooden coffin outside the granite sarcophagus, beads, pieces of mummy, all spread out around the rooms (fig. 3).

On November 6, 1994, a $68 \mathrm{~cm}$ high and $85 \mathrm{~cm}$ wide entrance was discovered at ground level in the center of the east wall of the shaft that leads to the burial apartment of queen Weret II. The opening was concealed by a mud coating that covered the brick fill of a small, slightly sloping passage $1.58 \mathrm{~m}$ long. The narrow gap between the top layer of brick and the ceiling was filled with flat limestone chips. At the east end of the north wall, a 53 $\mathrm{cm}$ wide side niche was found sealed by two limestone slabs, a lower one lying flat and covering a small pit and another standing on it (fig. 4). Gypsum was used to carefully cement both in place. After removing the stones, a $60 \mathrm{~cm}$ deep pit appeared, filled to its rim with soil. About 6.500 beads and fifty single elements of jewellery were found completely mixed with the soil. All strings had completely decayed, though a few scraps remained inside the beads and other elements. ${ }^{14}$ No identifiable remains of a box or any other receptacle were found, though it is possible that the objects were placed in a bag or another container made of a highly perishable material that vanished without a trace. Although the objects had remained untouched since they were deposited, it is uncertain whether the jewels were originally buried in this location; instead, it is possible that the jewellery deposit was originally placed elsewhere and, after an event difficult to determine, reburied in another place, although incomplete. ${ }^{15}$

The elements have been restored to complete pieces of jewellery so it is now possible to estimate the entity and features of the equipment, taking into account the possibility that included in the jewel boxes of royal women were loose items ${ }^{16}$ that were no longer associated with their original objects; such miscellaneous elements could have belonged to pieces of jewellery that had been broken or lost, had been remodelled to accommodate changes in fashion, or were remains of heirlooms ${ }^{17}$ (tab. 2).

3 Arnold 2002, 75.

14 Oppenheim 2002, 127.

15 According to Oppenheim, the lack of one or more pectorals and the remains of beads found in Weret II's north tomb seem to confirm that other jewellery was included in her funerary outfit (Oppenheim 2002, 127, fn. 9).

16 In their publications of the tomb of Sithathoriunet, Brunton and Winlock briefly consider the question of loose pieces (Brunton 1920, 42-43; Winlock 1934, 54).

17 Oppenheim 2002, 129. 


\begin{tabular}{|l|}
\hline \multicolumn{1}{|c|}{ JEWELLERY FROM THE TOMB OF QUEEN WERET II } \\
\hline \multicolumn{1}{|c|}{ RECONSTRUCTED JEWELS } \\
\hline Two djed-pillar bracelets \\
\hline Two claw-pendant anklets ${ }^{19}$ \\
\hline Cowrie-shell girdle \\
\hline Motto-clasp necklace \\
\hline Bracelet (?) with reef-knot amulets \\
\hline Two bracelets with lion amulets \\
\hline Two inscribed amethyst scarabs (originally belonged to rings) \\
\hline Blank turquoise scarab (originally belonged to ring) \\
\hline
\end{tabular}

Tab. 2: Schematic summary of the jewels discovered in the tomb of queen Weret II.

\section{THE ANKLETS OF PRINCESS KHNUMIT: A PROPOSAL FOR RECONSTRUCTION}

Anklets were certainly worn by women at least as early as the Badarian Period, and they remained a popular female fashion during the Old and Middle Kingdoms, to judge from representations. ${ }^{20}$

In the Middle Kingdom anklets were worn both by men and women; they are similar to the Old Kingdom type of anklet consisting of rows of beads threaded between spacerbars. $^{21}$

This kind of ornament for the legs is hard to distinguish from bracelets of the same construction; not only armlets but also anklets were often made to match bracelets, ${ }^{22}$ both in actuality and on the monuments they were made en suite. ${ }^{23}$ Generally, however, the anklets are not as wide as the bracelets, as testified - among others - from Lahun's jewels; ${ }^{24}$ moreover, the gold sliding bar-clasps of the anklets lack the inlaid decoration ${ }^{25}$ of the bracelets. ${ }^{26}$

During the Middle Kingdom, a new design of anklets appeared consisting of a double

18 Oppenheim 2002, 129-133; in the publication (presented as preliminary and missing illustrations) is given a complete list of any single element discovered and a description of the reconstructed jewels exhibited in the Egyptian Museum, Cairo, along with the Middle Kingdom jewellery found by De Morgan's excavations.

19 Oppenheim 1996, 26; Oppenheim 1999, 147; Comand 2001, 353; Oppenheim 2002, 129.

20 Andrews 1995, 160.

21 Wilkinson 1971, 61 .

22 Winlock 1934, 49. This is the case in the treasures of Sithathoriunet at Lahun (Brunton 1920, pl. IV; Winlock 1934, pls. X-XI), of Khnumit (De Morgan 1903, pl. V) and Weret II (Oppenheim 2002, 144, 147) at Dahshur, of Neferuptah (Farag - Iskander 1971, pls. XLI-LI) at Hawara.

23 Aldred 1971, 159

24 Brunton 1920, 33-35, pl. IV; Winlock 1934, 43-50, pls. X-XI.

25 In the bracelets of Mereret (De Morgan 1895, pl. XX) from Dahshur and of Sithathoriunet (Brunton 1920, pl. IV; Winlock 1934, pls X-XI) from Lahun we have the cartouche with the name of Amenemhat III; in the bracelets of Sithathor (De Morgan 1895, pls. XV-XVI), Ita (De Morgan 1903, pl. V) and Weret II (Oppenheim 2002, 138) from Dahshur is drawn the djed-pillar; in the bracelets of Khnumit (De Morgan 1903, pl. V; Oppenheim 2002, 144) from Dahshur is inlaid the sa-sign.

26 Hayes 1953, 235; Andrews 1995, 161. 
string of amethyst ball beads, ${ }^{27}$ closed by a gold knot-clasp from which hung a gold clawpendant, ${ }^{28}$ one facing right, the other left.

The first claw-pendants discovered in the treasures of the princesses of the XII dynasty were not correctly interpreted because they were found inside the casket instead of worn by the mummy; ${ }^{29}$ later, at Nag' el-Deir an undisturbed burial was found of a woman (N.453b) who was wearing on her ankles six silver claws and two of bone overlaid with bronze, threaded with small carnelian and amethyst beads. ${ }^{30}$ These latest pendants, larger and probably a substitute for gold, hung just above the anklebone on the outside of the foot. ${ }^{31}$

Usually only one claw was worn over the outer anklebone, but anklets exist where several claws are spaced at intervals on the same string of beads. ${ }^{32}$

In regard to a possible reconstruction, at that time the only possible solution was deemed to mount the inlaid claw-pendants of Khnumit on a single row of gold beads and, still today, they are on exhibit with this arrangement.

C. Aldred, in 1971, with his study of Egyptian jewels, already revealed the mistake made by mounting both pendants on a single string and proposed that, for a pair of anklets, one claw should be hung outside the ankle-bone; he also thought that the wires were made not only of gold beads, but also carnelian, turquoise and lapis lazuli, the same colours used for the pendant's inlays. ${ }^{33}$

The claw-shaped pendants from the burial of princess Khnumit, ${ }^{34}$ with a single suspension loop, are inlaid with turquoise, carnelian and lapis lazuli in cloisons to look like feathering ${ }^{35}$ (fig. 5). All these details are chiseled on the underside. A second pair of inlaid claws $^{36}$ comes from the more recent excavations of MMA in the tomb of Weret II at Dahshur ${ }^{37}$ and has this kind of decoration: narrow horizontal stripes of carnelian-turquoisecarnelian at the top; long, curving pieces of carnelian that follow the sweeping, tapering shapes of the claws were placed in the centers of the lower sections, surrounded on either side by alternating pieces of lapis lazuli and turquoise; the tips of the claws have lapis lazuli

27 The solid gold claws with chased details have two gold ball beads set one on top of the other for suspension; the inlaid claw-pendants, on which it will be said soon, usually have just a single suspension loop (Andrews 1995, 163).

28 For a list and a brief note about this typology of amulets, respectively: Andrews 1981, 95; Andrews $1994,66$.

29 The solid gold claws come from the tombs of Sithathor (De Morgan 1985, pl. XVII) and Mereret (De Morgan 1985, pl. XXII) at Dahshur and of Sithathoriunet (Brunton 1920, pl. VIII) at Lahun; the inlaid claws come from the tombs of Khnumit (De Morgan 1903, pl. V) and Weret II (Oppenheim 2002, 147) at Dahshur.

30 Eaton 1941, 94-98, fig. 3; Wilkinson 1971, 62.

31 Eaton 1941, 97, fig. 5.

Aldred 1971, 160

Aldred 1971, 180-181.

34 Materials: gold, carnelian, lapis lazuli, turquoise. Measures: 2.25 x $1.65 \mathrm{~cm}$; weight $3 \mathrm{~g}$.

35 Andrews 1995, 163. According to some scholars, the decoration suggests an interpretation for this elements as birds' claws (Winlock 1934, 36); but the claw-amulets in the treasures of Sithathoriunet at Lahun and of Mereret at Dahshur were found with girdle-beads representing leopard- or lioness-heads, so these claws might be related to the feline sphere (Wilkinson 1971, 62; Desroches-Noblecourt 1978, 281; Andrews 1994, 66; Romano 1995, 1610).

36 Materials: gold, carnelian, lapis lazuli, turquoise. Measures: 2.14 x 1.49 cm; 2.13 x $1.52 \mathrm{~cm}$.

37 Oppenheim 1996, 26; Oppenheim 1999, 147; Comand 2001, 353; Oppenheim 2002, 129. 
inlays, as does the rounded projection on the sides (fig. 6).

At the top of the claws are small gold barrel beads from which the pendants were suspended; they originally hung from two colourful anklets ${ }^{38}$ composed of twenty rows of minute beads arranged in alternate bands of lapis lazuli, carnelian and turquoise, each separated by bars composed of tiny gold beads that were soldered together ${ }^{39}$ (fig. 7).

Middle Kingdom jewels, as evidenced also by these anklets, show a vibrant and refined interest for polychromy which implies not only a modern aesthetic taste, but also a primary symbolic function. ${ }^{40}$

The semiprecious stones employed more frequently and "canonically" mixed with each other are carnelian, turquoise and lapis lazuli; ${ }^{41}$ these stones are not related to this short period of time but through successful jewellery production of the whole Egyptian dynastic history.

Since De Morgan's documentation is incomplete and inaccurate, its finding turned out to be useless for an accurate reexamination both of the investigated contexts and of the discovered materials. ${ }^{42}$

However, the presence of a large amount of gold spacer-bars and carnelian, turquoise and lapis lazuli beads in Khnumit's treasure allows us to suggest the reconstruction of a pair of anklets similar in type to those discovered in the jewellery deposit of Weret II (fig. 8).

The top of each claw is fitted with a tiny gold bead that probably was inserted between the beads on the inferior string of the anklets or, perhaps, into slots left open on two of the bars, as in the anklets of Weret II. ${ }^{43}$

\section{CONCLUSIONS}

The reconstruction here proposed is now possible through the comparison with Weret's anklets, not available to scholars who analyzed Egyptian jewels and attempted their reassembly before the ' 90 s of last century.

Further evidence to support such a hypothesis comes from a wall painting at Qaw elKebir (tomb 18) that shows a dancing-girl with a claw-pendant hanging from her ankles ${ }^{44}$ (fig. 9).

For the identification of claw-shaped pendants as ornaments for the legs, scholars used

38 JE 98784 A, B - 98789 - 98780 A, B - 98790 D - 98792 D - 98793 D. Materials: gold, carnelian, lapis lazuli, turquoise. Measures: L. $21.5 \mathrm{~cm}, \mathrm{H} 3.8 \mathrm{~cm}$.

39 Oppenheim 2002, 129-130.

40 For the extensive and interesting subject of the symbolic function of Egyptian mineral universe and more generally on the symbolic use of colour, see the contribution of S.H. Aufrère (1991); for a brief summary on materials and their symbolism: Andrews 1994, 100-106.

41 Vilímková - Abdul-Rahman 1968, 58; Romano 1995, 1606; Comand 2001, 338. By the Old Kingdom this tricolour-scheme of red, green-blue and deep blue had been established for royal and courtly jewels and eventually became the standard for all mixed-material creations (Markowitz 2001, 202).

42 Aldred 1971, 10; Andrews 1995, 16, 18.

43 Oppenheim 1999, 147; Oppenheim 2002, 129. The second hypothesis should be verified by an autopsy examination of the entire group of these elements found by De Morgan.

44 Petrie 1930, pl. XXIV. 
this painting without recognizing, despite the schematic design, that the anklets worn by the dancer are just the type with multiple rows of beads and spacer-bars, like that of Weret II, discovered just in 1994.

The anklets from the burials of royal women at Dahshur illustrate once more the typological variety, the formal and technical quality of royal jewellery during the XII dynasty.

\section{REFERENCES}

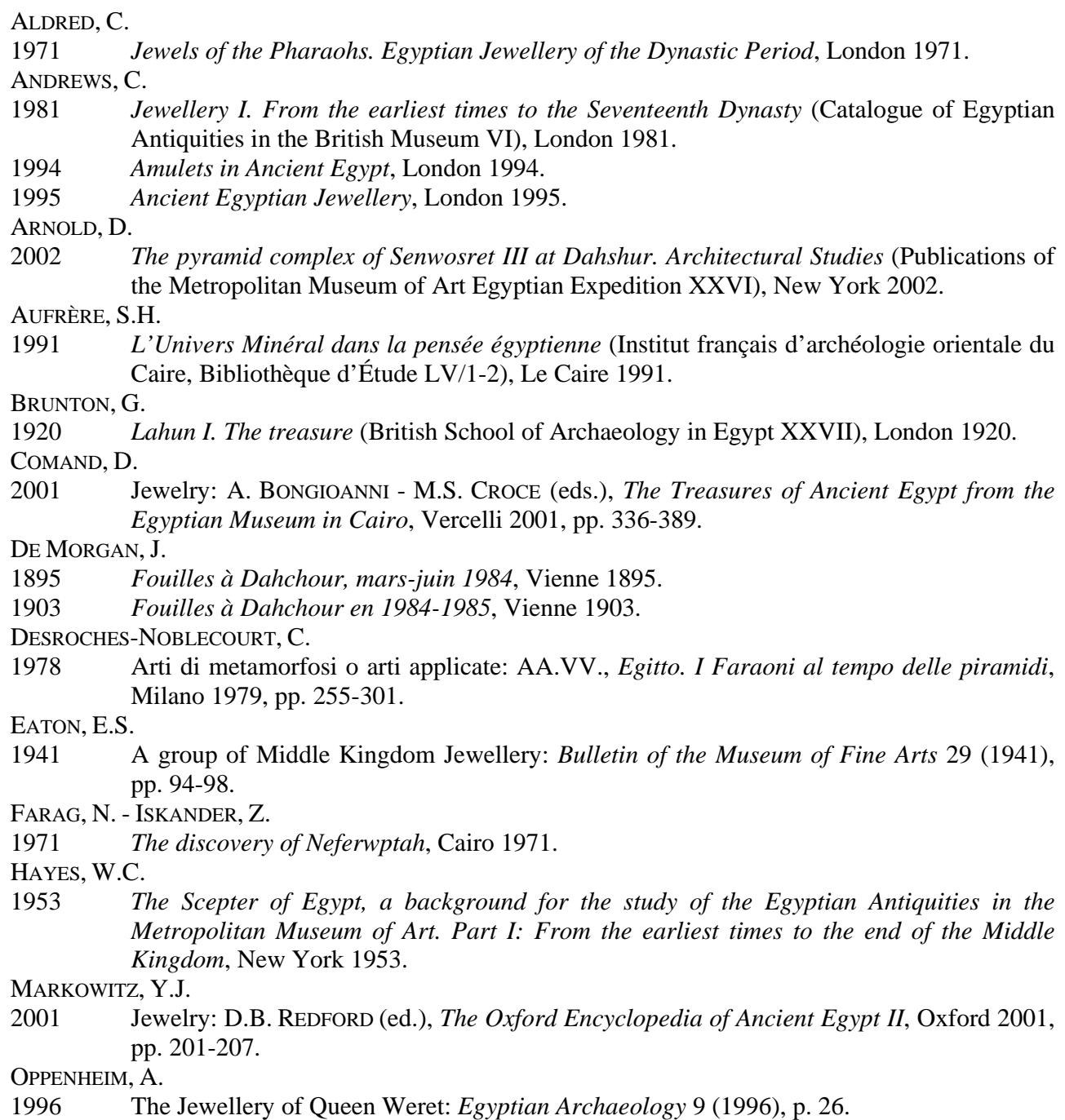


1999 The Royal Treasures of the Twelfth Dynasty: F. TIRADRITTI (ed.), Egyptian Treasures from the Egyptian Museum in Cairo, Vercelli 1999, pp. 137-153.

2002 Appendix: D. ARnold (ed.), The pyramid complex of Senwosret III at Dahshur. Architectural Studies (Publications of the Metropolitan Museum of Art Egyptian Expedition XXVI), New York 2002, pp. 123-146.

Petrie, W.M.F.

1930 Antaeopolis. The tombs of Qau (British School of Archaeology in Egypt LI), London 1930.

ROMANO, J.F.

1995 Jewelry and Personal Arts in Ancient Egypt: J.M. SAsson (ed.), Civilizations of the Ancient Near East III, New York 1995, pp. 1605-1621.

SCANDONE MATTHIAE, G.

2006 Una pietra per amica. Poteri magici e simbolismo religioso delle pietre preziose e VERNIER, E. semipreziose: Pharaon Magazine II/2 (2006), pp. 54-60.

1925 Bijoux et orfèvreries 3 (Catalogue général des antiquités égyptiennes du Musée du Caire), Le Caire 1925.

Vilimkova, M. - AbDul-Rahman, M.H.

1968 Altägiptische Gold Schmiedekunst, Prague 1968.

WILKINSON, A.

$1971 \quad$ Ancient Egyptian Jewellery, London 1971.

WINLOCK, H.E.

1934 The treasure of el Lahun (The Metropolitan Museum of Art, Department of Egyptian Art IV), New York 1934. 
Fig. 1: View from above and axonometric view of Ita and Khnumit's tombs in the funerary complex of Amenemhat II at Dahshur (after De Morgan 1903, figs. 96, 98).
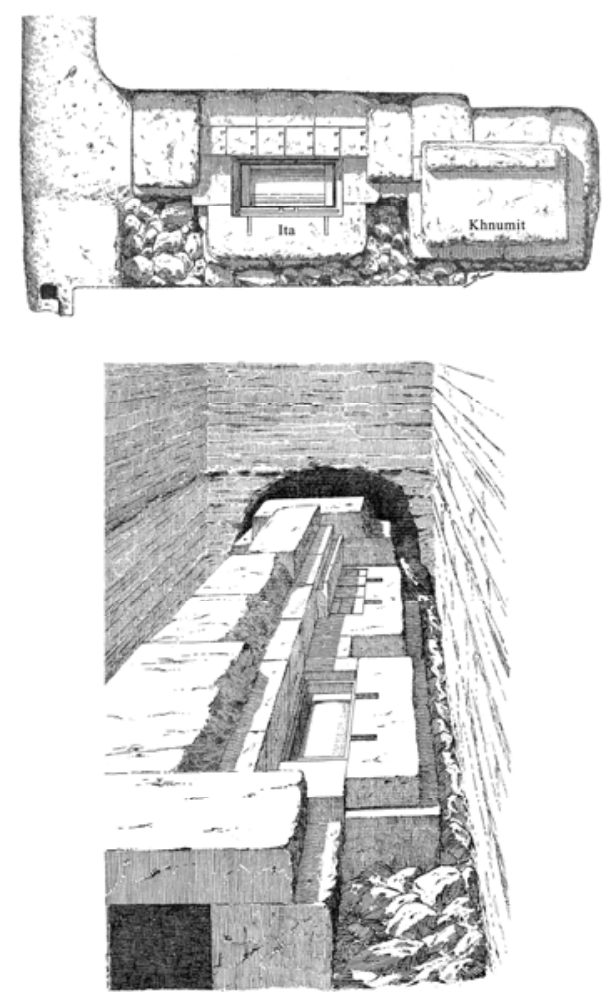

Fig. 2: Plan and sections of the north tomb of pyramid 9 (Weret II) in the funerary complex of Sesostris III at Dahshur (after Arnold 2002, pls. 57-58).
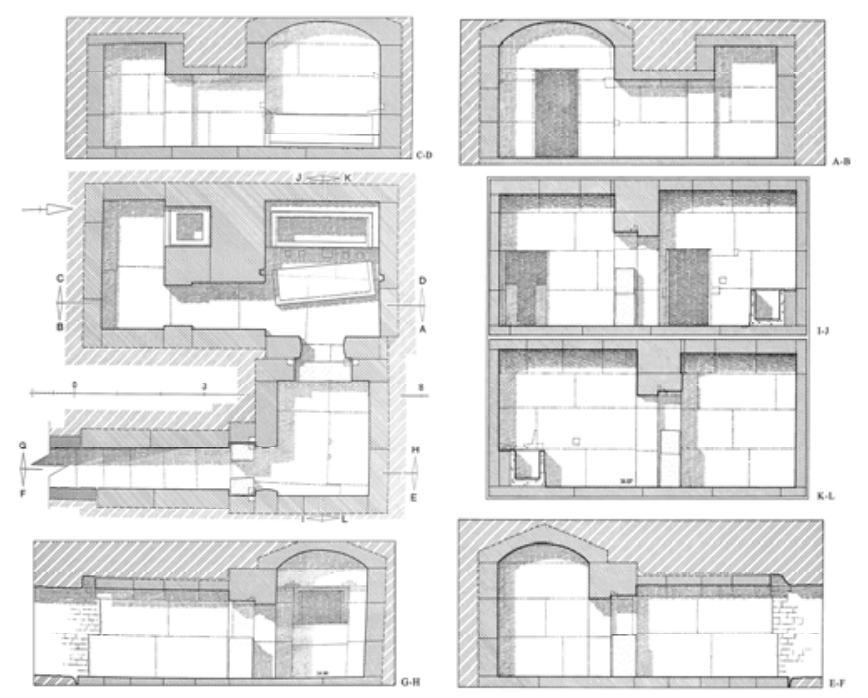


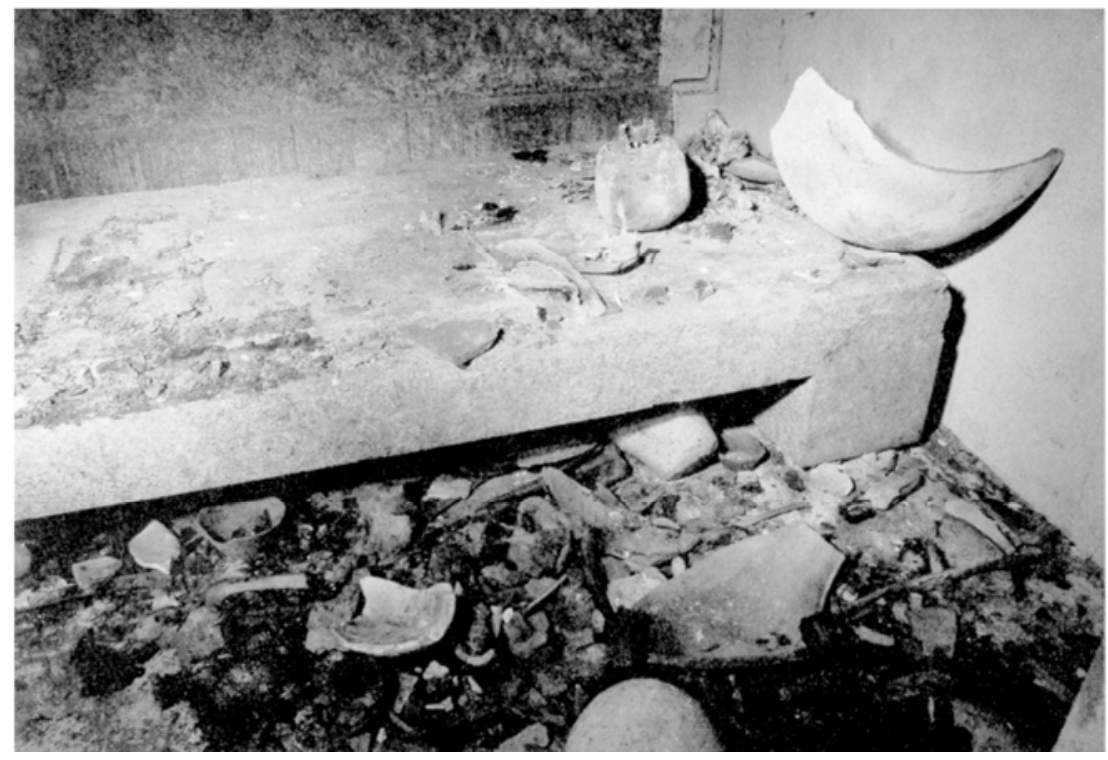

Fig. 3: Crypt as found, with overturned sarcophagus lid on the floor with the queen's skull on the right side of the lid, in the north tomb of pyramid 9 of Weret II (after Arnold 2002, pl. 64b).

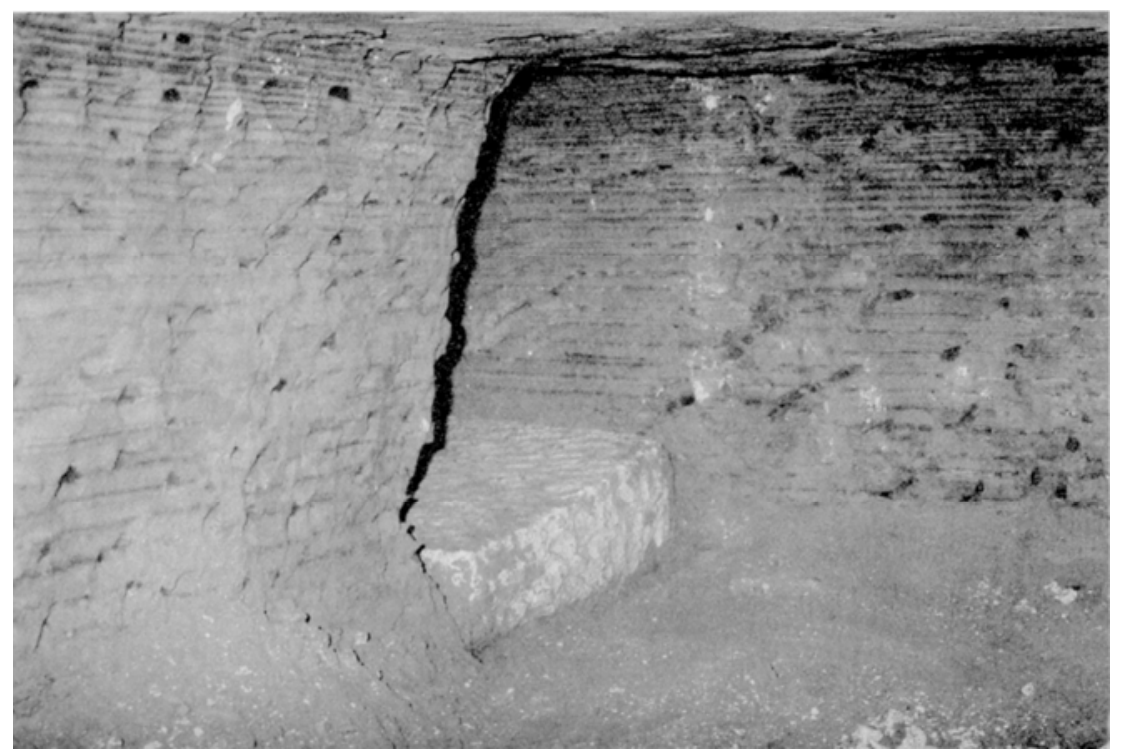

Fig. 4: Niche on the east side of the shaft that contained the jewellery deposit in pyramid 9 of Weret II (after Arnold 2002, pl. 64d). 

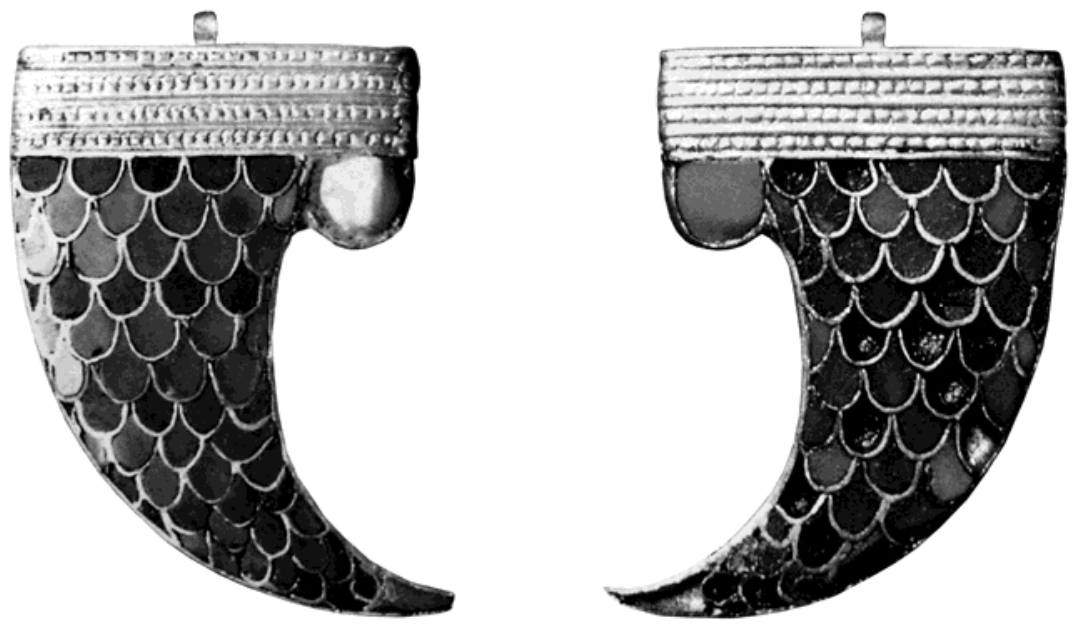

Fig. 5: The claw-shaped pendants from the burial of princess Khnumit at Dahshur (after Scandone Matthiae 2006, 55).
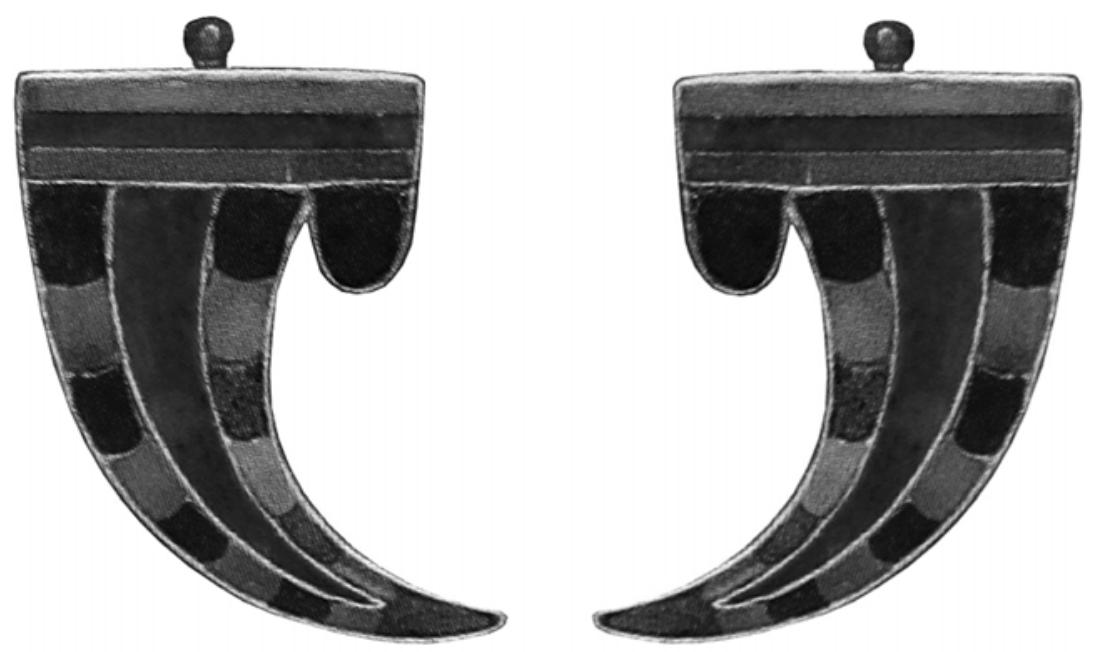

Fig. 6: Inlaid claws from the burial of queen Weret II at Dahshur (after Oppenheim 1999, 146-147). 

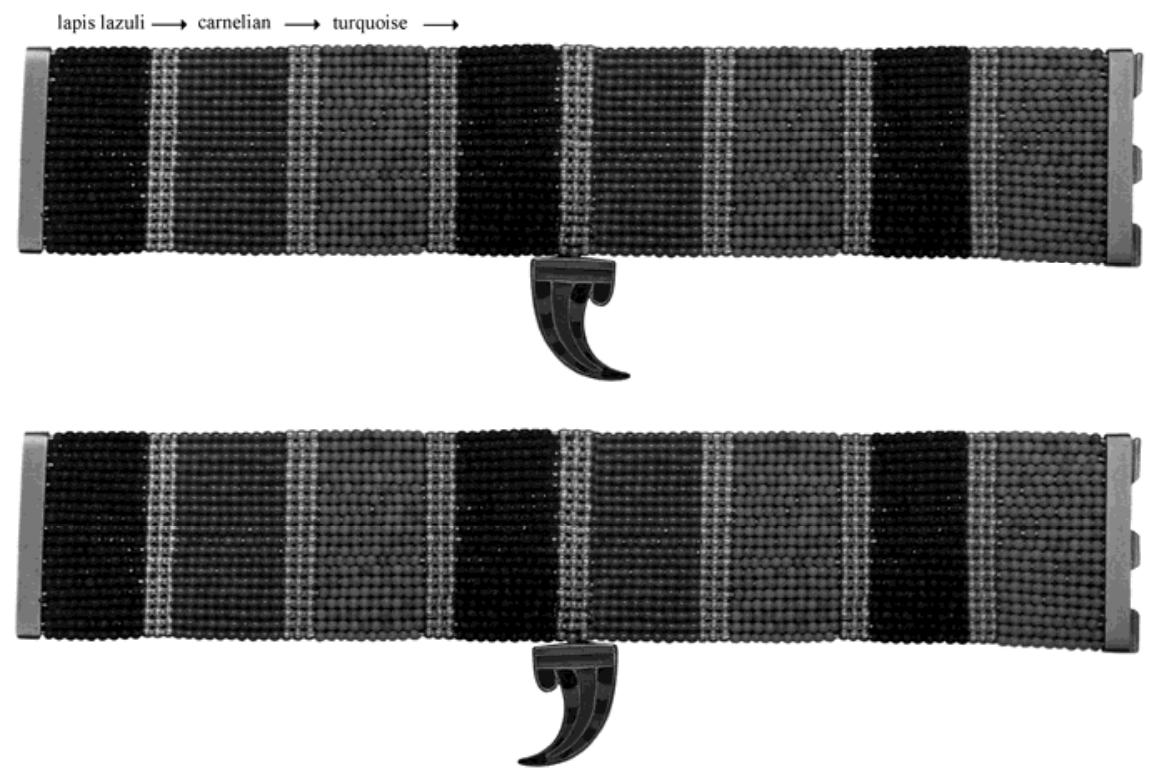

Fig. 7: Pair of claw-pendant anklets of queen Weret II, reconstruction (after Oppenheim 1999, 146-147).
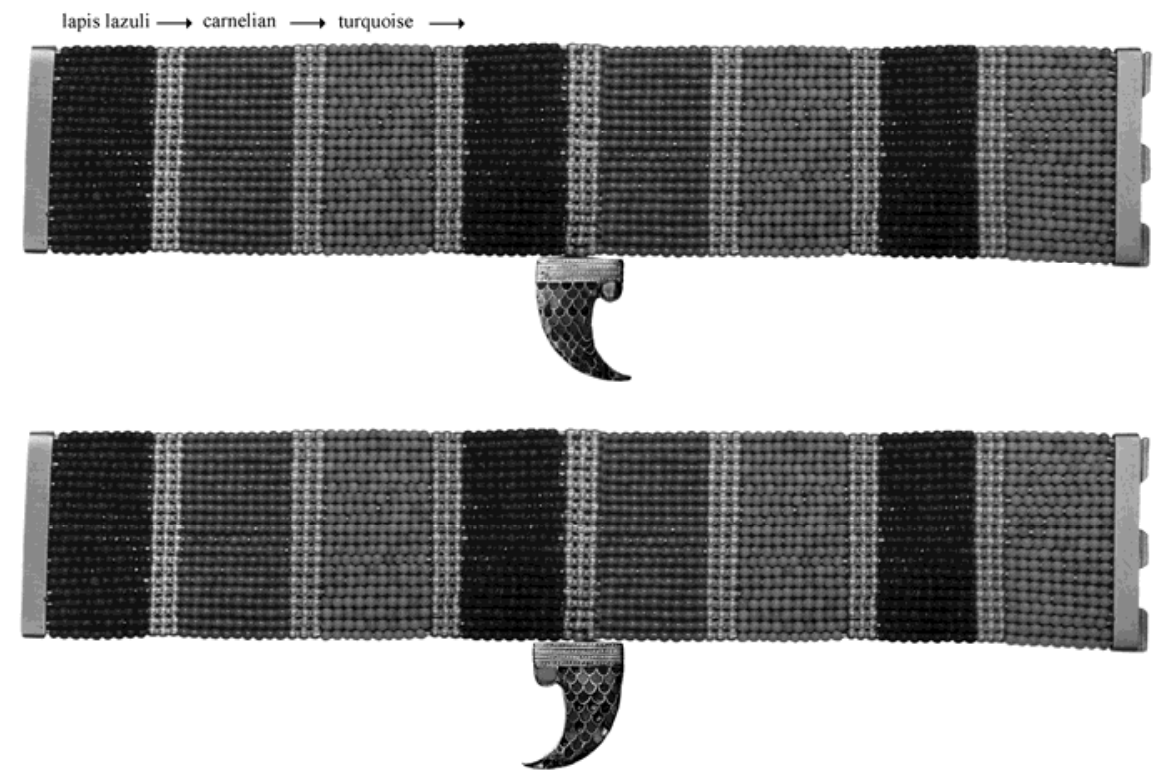

Fig. 8: Proposal for reconstruction of the claw-pendant anklets of princess Khnumit (after Oppenheim 1999, 146-147; Scandone Matthiae 2006, 55). 

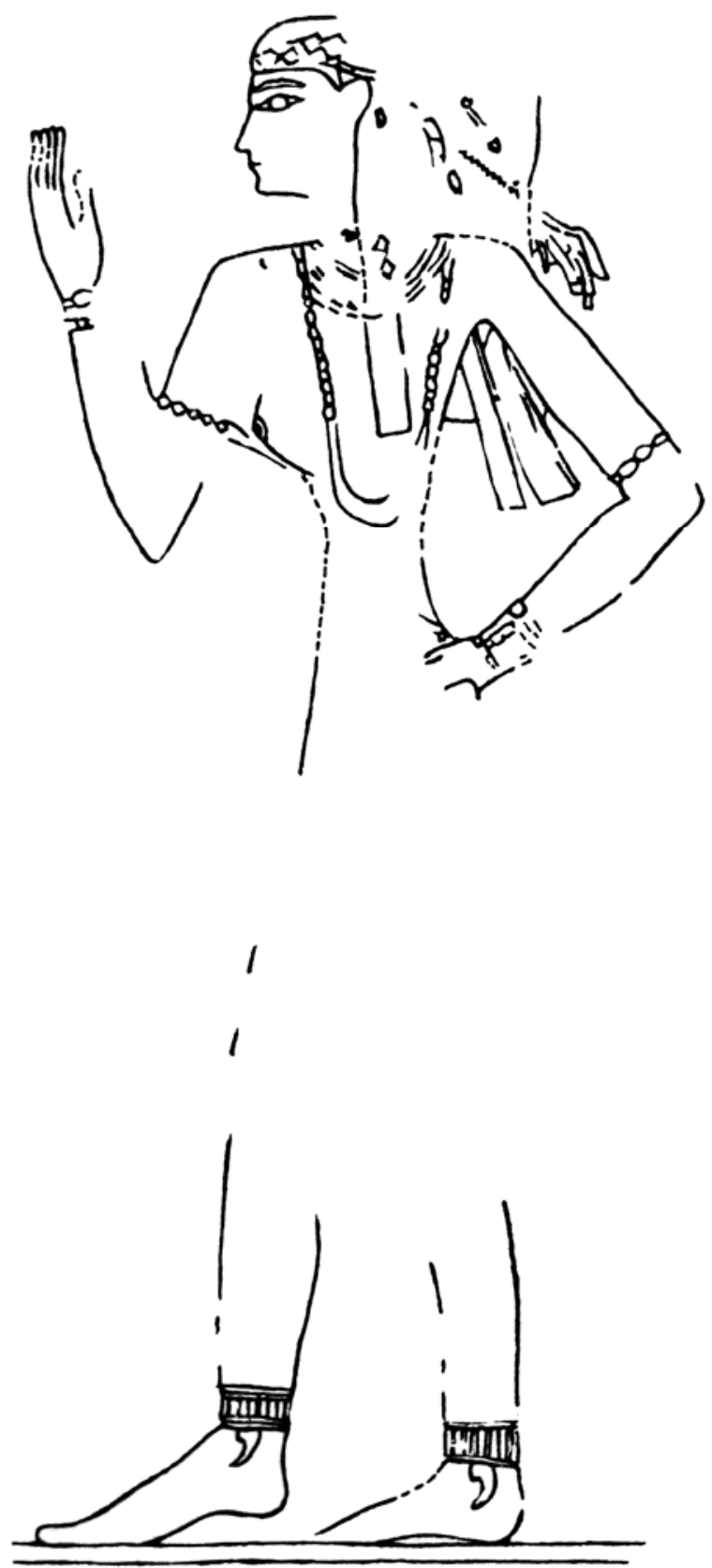

Fig. 9: Particular of a wall painting at Qaw el-Kebir (tomb 18) that shows a dancing-girl with a claw-pendant hanging from her ankles (after Petrie 1930, pl. XXIV). 